\title{
The Regulation Of OnLINe Dispute RESOLUTION: EFFECTIVENESS OF ONLINE CONSUMER PROTECTION GUIDELINES
}

\section{KanANKe Chinthaka LiyanAgE*}

Regulation of online dispute resolution (ODR) has become an important element in the conceptualisation of its role as an appropriate dispute resolution mechanism. Given the lack of specific legislation regarding ODR nationally and internationally, there is a growing tendency towards seeking appropriate regulatory models for its regulation in the ODR literature, international organisations, governments and the private sector. While recognising the valuable contributions made in all these fields, this article maps the regulatory approaches for ODR adopted by governments in the Guidelines for Consumer Protection in the Context of Electronic Commerce developed by the Organisation for Economic Co-operation and Development in 1999 and the Australian Guidelines for Electronic Commerce in 2006. In addition, the viability of the regulatory approaches of these instruments is explored in the context of online consumer arbitration used for the resolution of cross-border business-to-consumer electronic commerce disputes. In the course of the discussion, some insights on further improvements to these guidelines are also provided.

\section{INTRODUCTION}

Online dispute resolution (ODR) mechanisms which can be utilised for the resolution of business-to-consumer electronic commerce disputes (B2C ecommerce disputes) are required to exist within a secure legal framework. Developments as to the regulation of online dispute resolution (ODR) can be seen mainly in three areas: in the ODR literature, in the private sector, and in the government sector. ${ }^{1}$ As far as the ODR-related literature is concerned, Lodder and Bol are of the view that '[n]ot only legal principles like fair trial are put into a novel perspective, but also new principles specifically directed at the online environment are needed. Therefore the drafting of legal principles for ODR is

\footnotetext{
* LLB (Sri Lanka), LLM (Melbourne); Attorney at Law (Sri Lanka), PhD Candidate in law at La Trobe University, Melbourne; Lecturer in Law, University of Colombo, Sri Lanka.

${ }^{1}$ See, eg, Uniform Dispute Resolution Policy adopted by the Internet Corporation for Assigned Names and Numbers (ICANN) reflects the commitment made by the private ODR sector: ICANN, Uniform Domain Name Dispute Resolution Policy (26 August 1999) $<$ http://www.icann.org/en/dndr/udrp/policy.htm>.
} 
important'. ${ }^{2}$ Morek argues that 'a solid legal framework is needed to allow for the proper growth of online dispute resolution with its norms, market and technology'. ${ }^{3}$ Cortes indicates that 'the establishment of a legal framework in the ODR field for B2C disputes will increase legal certainty, facilitating the expansion of quality and fair ODR methods'. ${ }^{4}$ By examining hard law and soft law options for the regulation of ODR, Vilalta notes that 'model laws and legislative guides, due to their particular features, may be more suitable instruments than conventions for the progressive harmonization of practices and laws in ADR/ODRs matters'. ${ }^{5}$

Secondly, in the private ODR sector, there are providers that operate within a regulatory framework designed by themselves; for example, the Uniform Dispute Resolution Policy's (UDRP) ICAAN Rules and supplemental rules adopted by UDRP providers, which are used for the resolution of domain name disputes. ${ }^{6}$ Another example is NetNeutrals.com, which has developed rules and guidelines for its ODR mechanisms. ${ }^{7}$

Thirdly, even though there is not yet any specific legal instrument nationally or internationally which is particularly designed for ODR, governments have developed regulatory measures in the context of online consumer protection which can arguably be related to the regulation of ODR. Online consumer protection guidelines such as the Organisation for Economic Co-operation and Development (OECD) Guidelines, ${ }^{8}$ the Australian Guidelines, ${ }^{9}$ national consumer protection laws which include the Competition and Consumer Act 2010 (Cth) (CCA), and e-commerce-friendly laws such as the Electronic Transactions Act 1999 (Cth), can be cited as examples.

2 Arno R Lodder and Stephanie H Bol, 'Towards an Online Negotiation Environment: Legal Principles, Technical Requirements and the Need for Close Cooperation' (2003) November ADRJ Online Monthly <http://pubs.cli.vu/pub163.php>.

${ }^{3}$ Rafal Morek, 'Regulation of Online Dispute Resolution: Between Law and Technology' (2005) $76<$ http://www.odr.info/cyberweek/Regulation\%20of\%20ODR_Rafal\%20Morek.doc>.

${ }^{4}$ Pablo Cortes, 'Accredited Online Dispute Resolution Services: Creating European Legal Standards for Ensuring Fair and Effective Processes' (2008) 17(3) Information \& Communications Technology Law 221, 224.

${ }^{5}$ Aura Esther Vilalta, ‘Legal Framework and Harmonization of ADR/ODR Methods' (2010) 2(7) Journal of Law and Conflict Resolution 103, 106.

${ }^{6}$ ICANN, above $n 1$.

${ }^{7}$ NetNeutrals.com, Rules \& Guidelines, <http://netneutrals.com/rulesnn.asp>.

8 OECD, Recommendation of the OECD Council Concerning Guidelines for Consumer Protection in the Context of Electronic Commerce (1999) ('OECD Guidelines') <http://www.oecd.org/document/50/0,3343,fr_2649_34267_1824435_1_1_1_1,00.html>.

9 The Treasury, the Australian Guidelines for Electronic Commerce (2006) ('Australian Guidelines')

$<$ http://archive.treasury.gov.au/documents/1083/PDF/australian_guidelines_for_electronic_com merce.pdf $>$. 
From the perspective of the regulation of ODR, the question is how effectively ODR, including online commercial arbitration (OCA), has been secured by the existing regulatory frameworks, given the context of the recognition of ODR mechanisms as an appropriate dispute resolution mechanism for B2C e-commerce disputes. ${ }^{10}$ The purpose of this article is to explore governments' response to the regulation of ODR, specifically the viability of the regulatory approaches adopted in the OECD Guidelines and Australian Guidelines in terms of the regulation of ODR in general and OCA in particular. This exploration is restricted to the OECD Guidelines and Australian Guidelines because of their special focus on the protection of online consumers and setting of principles that should be reflected in dispute resolution mechanisms for them to be appropriate for the resolution of B2C e-commerce disputes.

It is here argued that the current regulatory approaches adopted in these instruments, which are considered nationally (Australian Guidelines) and internationally (OECD Guidelines) applicable benchmarks for online consumer protection, ${ }^{11}$ is not wholly workable (while not detrimental itself) in terms of regulating ODR, due to several drawbacks existing in these guidelines. Before moving to support this argument, there is an introduction to the relationship between ODR and e-commerce, followed by an outline of the scope of both sets of Guidelines with their objectives and legal status. The article will then briefly review the literature in terms of regulatory models for ODR to provide insight into the theoretical underpinnings of the debate over the regulation of ODR. Next, a detailed commentary on the viability of regulatory approaches adopted by the OECD Guidelines and the Australian Guidelines in light of ODR in general and OCA in particular is pursued. In the course of the discussion, some insights on further improvements to the guidelines are also provided.

\section{ODR AND B2C E-commerce SETtING}

Brief attention to special features that can be recognised as connecting factors between ODR and electronic commerce is warranted. One such factor could be the development of ODR as part of the broader e-commerce market. In this regard, it is important to identify the scope of electronic commerce. Wigand articulates the scope of electronic commerce in the following terms:

\footnotetext{
${ }^{10}$ See generally Eugene Clark and Arthur Hoyle, ' E-ADR: On-Line Dispute Resolution: Issues and Recent Developments’ (2002) 8 <http://www.canberra.edu.au/ncf/publications/e-adr.pdf>.

${ }^{11}$ Lisa Smith, 'Global Online Shopping: How Well Protected is the Australian Consumer?' (2004) 12 Competition \& Consumer Law Journal 163, 168.
} 
Broadly speaking, electronic commerce includes any form of economic activity conducted via electronic connections. The bandwidth of 'electronic commerce' spans from electronic markets to electronic hierarchies and also incorporates electronically supported entrepreneurial networks and cooperative arrangements (electronic networks). The market coordination mechanism is their common characteristic. Services within the tourism, finance, or insurance industries, but also product distribution and customer services, are typical fields of application. ${ }^{12}$

It is evident that '[a]n e-commerce transaction is a means of performing commercial activities using the global digital e-commerce infrastructure'. ${ }^{13}$ The Internet has created a number of vibrant e-commerce business settings, such as transactions that take place business to business (B2B), business to consumer (B2C), consumer to business (C2B) and consumer to consumer (C2C) in the online context. ${ }^{14}$ Importantly, the application of both the OECD Guidelines and Australian Guidelines is limited to the B2C e-commerce setting. ${ }^{15}$ As far as the B2C electronic setting is concerned, online consumers transact with online businesspeople 'located far from each other'. ${ }^{16}$ One likely outcome of their online contracts is an increase in disputes between online businesses and online consumers, demanding appropriate dispute resolution mechanisms. ${ }^{17}$ Gilliéron also asserts that ' $[\mathrm{t}]$ he growth of e-commerce is bound to be linked with online disputes'. 18

${ }^{12}$ Rolf T Wigand, 'Electronic Commerce: Definition, Theory, and Context' (1997) 13(1) The Information Society: An International Journal 1, 2.

13 Saleh Alfuraih and Richard Snow, 'ODR and the E-commerce' (2005) $<$ http://faculty.ksu.edu.sa/ALFURAIH/csc483/Alfuraih6_ODR_and_the_E-Commerce.pdf>.

14 DigitSmith, ecommerce definition and types of ecommerce $<$ http://www.digitsmith.com/ecommerce-definition.html>.

${ }^{15}$ OECD Guidelines, above n 8, pt 1; Australian Guidelines, above n 9, Guideline 8.

${ }^{16}$ Europa, 'Alternative Dispute Resolution and Online Dispute Resolution for EU Consumers: Questions and Answers' (Press Release, MEMO/11/840, 29 November 2011) $<$ http://europa.eu/rapid/pressReleasesAction.do?reference=MEMO/11/840>; Julia Hörnle, 'Online Dispute Resolution - More than the Emperor's New Clothes' (Paper presented at UNECE Forum on ODR, 2003) 1 <http://www.mediate.com/Integrating/docs/Hornle(1).pdf>.

17 See also Haitham A Haloush and Bashar H Malkawi, 'Internet Characteristics and Online Alternative Dispute Resolution’ (2008) 13 Harvard Negotiation Law Review 327, 330. Carneiro et al argue that '[i]f a transaction occurs online, then disputants are likely to accept online techniques to resolve their disputes. Thus the development of e-commerce requires new ways of resolving conflicts. New ways of dispute resolution are hence appearing, so that the disputant parties neither need to travel nor to meet in courtrooms or in front of arbitrators or mediators' Davide Carneiro, Paulo Novais, Francisco Andrade, John Zeleznikow, José Neves, 'Online Dispute Resolution: An Artificial Intelligence Perspective’ (2012) 2 Artificial Intelligence Review <http://nlp.hivefire.com/articles/share/27433/>.

${ }^{18}$ Philippe Gilliéron, 'From Face-To-Face to Screen-To-Screen: Real Hope or True Fallacy?' (2007) 3 <http://works.bepress.com/philippe_gillieron/1/>. 
Importantly, ODR 'recently emerged as a set of tools and techniques, supported by technology, aimed at facilitating conflict resolution'. ${ }^{19}$ The rationale behind this novel online aspect of ODR mechanisms is that the same medium which has contributed to the emergence of online disputes should be used to resolve those disputes which emerge out of electronic commerce activities. ${ }^{20}$

Accordingly, the technological element of ODR can also be demonstrated through its definitions. For example, Hörnle defines ODR as a dispute resolution mechanism 'carried out by combining the information processing powers of computers with the networked communication facilities of the Internet'21 and 'the use of online communication technology in the resolution process, even if the dispute itself has an offline origin'. ${ }^{22}$

Importantly, ODR is recognised as covering a multiplicity of techniques: Lipsky and Avgar note that 'ODR is not a single phenomenon but in fact an umbrella term for a wide array of dispute resolution procedures and technological tools'. ${ }^{23}$ Accordingly, online arbitration is one mechanism out of several ODR mechanisms. ${ }^{24}$ The definition of online arbitration entails a dispute resolution mechanism conducted by a third party who resolves a dispute and delivers a binding decision by considering the merits of the arguments of the both parties. $^{25}$

Importantly, it must also be noted that ODR is not limited to the resolution of B2C e-commerce disputes; it has broader application. At present, ODR is used

\footnotetext{
${ }^{19}$ Carneiro et al, above $n 17$.

20 'It is logical to use the same medium (the Internet) for the resolution of disputes and where the parties are frequently located far from each other': Hörnle, above n 16, 1.

${ }^{21}$ Julia Hörnle, Cross-Border Internet Dispute Resolution (Cambridge University Press, 2009) 75.

${ }^{22}$ Ibid 650 .

${ }^{23}$ David B Lipsky and Ariel C Avgar, 'Online Dispute Resolution through the Lens of Bargaining and Negotiation Theory: Toward an Integrated Model' (2006) 38 University of Toledo Law Review 47, 48. According to Pablo Cortes, 'the most significant ODR methods for resolving consumer disputes, which are automated negotiation, assisted negotiation, mediation, arbitration and small claims court procedures': Pablo Cortes, 'The Potential of Online Dispute Resolution as a Consumer Redress Mechanism' (6 July 2007) $<$ http://papers.ssrn.com/sol3/papers.cfm?abstract_id=998865>.

${ }^{24}$ Thomas Schultz, 'Does Online Dispute Resolution Need Governmental Intervention? The Case for Architectures of Control and Trust' (2004) 6 North Carolina Journal of Law \& Technology 71,73 n 4.

${ }^{25}$ Arun Raghu, 'The Legal Challenges facing Online Dispute resolution: An Overview’ (2007) 9(9) Internet Law Bulletin <http://www.galexia.com/public/research/articles/research_articlesart42.html>.
} 
in diverse environments, for example 'domain names', 'insurance', 'privacy', 'family', 'employment' and 'commercial ${ }^{26}$ and in the traditional court setting in the form of government-sponsored electronic courts. ${ }^{27}$

The following section outlines the scope of the guidelines together with their objectives and legal status, followed by a brief literature review of the regulation of ODR and a detailed discussion of the viability of the regulatory approaches adopted in the OECD Guidelines and Australian Guidelines.

\section{The Rationale Behind the DeVelopment of OECD AND AUSTRALIAN GUIDELINES}

The OECD Guidelines were promulgated by the OECD council in 1999 after consultation with member countries, business and consumer organisations. These guidelines were product of 'the OECD Committee on Consumer Policy' which 'began to develop a set of general guidelines to protect consumers participating in electronic commerce without erecting barriers to trade'. The OECD Guidelines include many objectives. They contain a framework and a set of principles to assist bodies such as governments, business associations, consumer groups, self-regulatory bodies and individual businesses and consumers, with a view to providing effective consumer protection in the context of electronic commerce.

One of the objectives of the OECD Guidelines is to provide a framework and principles for governments to use when 'reviewing, formulating and implementing consumer and law enforcement policies, practices, and regulations' for the purpose of providing effective online consumer protection. Another objective is that business associations, consumer groups and selfregulatory bodies are provided with guidance for them to consider online consumer protection 'in reviewing, formulating, and implementing selfregulatory schemes in the context of electronic commerce'.

Importantly, the OECD Guidelines include a set of guidelines in terms of jurisdiction, applicable law and dispute resolution mechanisms which have particular importance and relevance to the resolution of B2C e-commerce

${ }^{26}$ Building Trust in the Online Environment: Business to Consumer Dispute Resolution, Joint Conference of the OECD, Orientation Document (11-12 December 2000) 37 $<$ http://search.oecd.org/officialdocuments/displaydocumentpdf/?doclanguage=en\&cote=dsti/icc $\mathrm{p} / \mathrm{reg} / \mathrm{cp}(2001) 2>$.

${ }^{27}$ Tania Sourdin and Chinthaka Liyanage, 'The Promise and Reality of Online Dispute Resolution in Australia' in Mohamed S Abdel Wahab, Ethan Katsh and Daniel Rainey (eds), Online Dispute Resolution: Theory and Practice a Treatise on Technology and Dispute Resolution (eleven International Publishing, 2012) 471-97. 
disputes as part of the broader objective of online consumer protection. The latter parts of this article offer a framework for achieving these goals and recommended several ways to establish global co-operation with a view to providing effective online consumer protection.

The first major response of the Australian government as an OECD member country towards developing an e-consumer protection policy framework can be seen in the initial policy document The Australian E-commerce Best Practice Model in 2000. This was repealed when the Australian Guidelines were introduced in 2006 in light of the OECD Guidelines, which are still current.

In general, as far as the objectives of the Australian Guidelines are concerned with the regulation of ODR, the following are worth noting. The Australian Guidelines focus on online consumer protection and the promotion of the B2C e-commerce market by incorporating several principles. They include: the establishment of fair business practices; accessibility to the electronic delivery of goods and services; guidelines regarding advertising and marketing; and protective guidelines in regards to minors. ${ }^{28}$ Additionally, the Australian Guidelines encourage businesses to provide information about their business and contractual arrangements, which facilitates consumers' awareness before any agreement between business and consumers takes place.

In line with these objectives, the Guidelines are available in terms of 'the law and forum for the resolution of contractual disputes' and 'the establishment of fair and effective procedures for handling complaints and resolving disputes'. It is clear that the Australian government's policy approaches towards the regulation of appropriate dispute resolution mechanisms for B2C e-commerce disputes are reflected in the Australian Guidelines.

In common, both instruments provide a set of guidelines which lack binding force. The OECD states that ' $[\mathrm{t}]$ hese guidelines represent a recommendation to governments, businesses, consumers, and their representatives'. A similar position in terms of its impact on 'existing laws and regulation' is reflected in the Australian Guidelines, as in the following:

11. The Guidelines are not a replacement for consumer protection laws or codes of conduct. Complying with the Guidelines does not exempt a business from compliance with obligations under such laws or codes.

\footnotetext{
${ }^{28}$ Australian Guidelines, above n 9, Guideline 10.
} 
12. Every effort has been made to avoid inconsistencies with existing laws. However, if there is an inconsistency, the law has precedence over the Guidelines.

13. Some parts of the Guidelines reflect legal requirements. Businesses should not rely on the Guidelines as a definitive statement of these requirements. Also, not all legal requirements relevant to electronic commerce are reflected in the Guidelines.

Basically, the rationale behind the development of these guidelines is to protect online consumers in transactions with online businesses over the internet. Under this rationale, it can be argued that there are standards embedded in both of these OECD Guidelines and the Australian Guidelines reflecting the commitment of the OECD and Australian government towards bringing alternative dispute resolution (ADR) and ODR into a recognised legal framework to ensure online consumer protection, especially those who encounter disputes in the B2C cross-border context. As such, it is worthwhile identifying the regulatory models and their scope enshrined in the OECD Guidelines and the Australian Guidelines, as part of the debate over the regulation of ODR in the ODR-related literature.

\section{DEBATE IN ODR LiteratuRE}

Whether ODR should be regulated is an ongoing debate in the ODR literature. Some writers note that there are philosophical differences between countries. For example, by referring to the European Union (EU), North America and Australia, Clark and Hoyle indicate that 'Europeans generally are not trusting of private regulation. They are accustomed to more government intervention to get these matters right'. ${ }^{29}$ This assertion can arguably be further supported by an example. The recently proposed '[p]roposal for a Regulation of the European Parliament and of the Council on online dispute resolution for consumer disputes' in $2011^{30}$ under which 'EU countries will be free to create their national rules to make the participation of traders in ADR procedures mandatory or their outcome binding on traders'. ${ }^{31}$ As far as the United States and Australia

\footnotetext{
${ }^{29}$ Clark and Hoyle, above n 10, 5.

${ }^{30}$ Regulation (EC) 2011/0374 of the European Parliament and of the Council on Online Dispute Resolution for Consumer Disputes [2011] OJ.

${ }^{31}$ Europa Press Release, above n 16: 'The European Parliament and the Council have already expressed their commitment to adopting the legislative package on ADR and ODR by the end of 2012, as part of coordinated efforts to re-launch the Single Market.'
} 
are concerned, 'there is much more faith in and reliance on industry to lead the way and govern itself'. 32

The Arbitration Fairness Act 2011 (US) which is designed to remove unfair aspects of binding arbitration exists still in the form of a bill and the liberal approach adopted by the judiciary in regard to mandatory OCA clauses from the American perspective can be cited as examples for the support of the United States approach. ${ }^{33}$ These two authors view in terms of Australian government's regulatory approach can be justified with the examples such as the development of standards which non-binding in nature for the regulation of ODR in the broader context of ADR taking into consideration offline and online context, eg, standards developed by the National Alternative Dispute Resolution Advisory Council (NADRAC) for ADR mechanisms ${ }^{34}$ and online consumer protection standards embedded in the Australian Guidelines. In fact, as far as the Australian approach to the regulation of ODR is concerned in light of the recent legislative developments which can be applied to the regulation of ODR, it can be argued that Australian regulatory approach seems to favour more government involvement. For example, unfair contract terms-related statutory framework embedded in the Australian CCA can be applied to the enforceability of ODR clauses.

Importantly, many scholars advocate diverse regulatory approaches which could be applicable to ODR because of the absence of a specific regulatory approach to ODR. According to Gibbons, the following options are available for the regulation of ODR:

First, governments may affirmatively regulate ODR by accrediting ODR providers and establishing de jure standards for B2C ODR services. Second, governments may elect a laissez-fair approach and permit e-commerce to create institutions that support a market for dispute resolution services and

${ }^{32}$ Clark and Hoyle, above n 10, 5.

${ }^{33}$ See generally Michael L Rustad, Richard Buckingham, Diane D’ Angelo and Katherine Durlacher, 'An Empirical Study of Predispute Mandatory Arbitration Clauses in Social Media Terms of Service Agreements' (Legal Studies Research Paper Series, 20 April 2012) $<$ http://papers.ssrn.com/sol3/papers.cfm?abstract_id=2043199>.

34 NADRAC, The Development of Standards for ADR (2000) $<$ http://www.nadrac.gov.au/publications/PublicationsByDate/Pages/DevelopmentofStandards.as px>; NADRAC, Suggestions to Help You when Resolving Disputes $<$ http://www.nadrac.gov.au/publications/DisputeResolutionGuide/Pages/SuggestionstoHelpYou WhenResolvingDisputes/4-6ADRstandards.aspx $>$; Mediator Standards Boards, National Mediator Accreditation Standards <http://www.msb.org.au/mediator-standards/standards $>$. 
permit that market to define the standards for consumer dispute resolution. Between these two extremes, there is a third option, the hybrid approach. ${ }^{35}$

Schultz addresses three modalities: accreditation, ${ }^{36}$ clearinghouses ${ }^{37}$ and online appeals. ${ }^{38}$ Morek examines four modalities for the regulation of ODR, ${ }^{39}$ of which law and norms appear to bear similar characteristic to government regulation and self-regulation. The other two, namely the market and technology, can arguably be considered different models with respect to the above mentioned list. Importantly, by looking at the theoretical and practical foundation of international commercial arbitration, Patrikios argues:

[T] he optimum solution is a truly international, decentralised, multistakeholder, multi-level and multi-instrument co-regulatory system based on ODR and centred on transnational online arbitration with the role of the courts limited to the guardianship of public policy. ${ }^{40}$

Patrikios further argues for the need for Lex informatica ('the body of transnational substantive rules of e-business law and usages, as well as the method of their application for the resolution of e-disputes by arbitration') ${ }^{41}$ as an appropriate approach 'to the proliferation of online arbitration and the coregulation of cross-border e-business' ${ }^{42}$

${ }^{35}$ Llewellyn Joseph Gibbons, 'Creating a Market for Justice; a Market Incentive Solution to Regulating the Playing Field: Judicial Deference, Judicial Review, Due Process, and Fair Play in Online Consumer Arbitration' (2002) 23 Northwestern Journal of International Law \& Business 1, 5-6.

36 'Furthermore, it permits regulation: The regulatory framework of a trustmark is made up of the conditions for granting it, and these conditions can be easily connected to a set of substantive rules': Schultz, above n 24, 96.

${ }^{37}$ Ibid 97-8: 'A second modality of ODR regulation is control of access to ODR providers. I contend that this modality permits the regulation of ODR in different formats because it allows the control of different aspects of access to ODR providers ... Such a clearinghouse would be able to regulate in three ways: (1) by controlling information about ODR providers, (2) by controlling filing, and (3) by reputation set against the rules of the clearinghouse.'

${ }^{38}$ Ibid 100: 'The third modality of ODR provider regulation is control of the providers work on a case-by-case basis.'

${ }^{39}$ Rafal Morek, 'The Regulatory Framework for Online Dispute Resolution: A Critical View' (2006) 38 University of Toledo Law Review 163.

${ }^{40}$ Antonis Patrikios, 'The Role of Transnational Online Arbitration in Regulating Cross-Border EBusiness - Part I' (2008) 24(1) Computer Law \& Security Review 1 $<$ http://www.sciencedirect.com/science/article/pii/S0267364907001094>.

${ }^{41}$ Antonis Patrikios, 'Resolution of Cross-Border E-Business Disputes by Arbitration Tribunals on the Basis of Transnational Substantive Rules of Law and E-Business Usages: The Emergence of the Lex Informatica' (2006) 38 University of Toledo Law Review 271, 274.

${ }^{42}$ Ibid 272. 
The next question is: what is the rationale behind these regulatory approaches? By referring to the OECD Guidelines with regards to online consumers, Calliess indicates that ' $[t]$ he guiding idea behind this call for self-regulation was that the advent of the Internet enables cross-border b2c-e-commerce'. ${ }^{43}$ The reason is that 'multi-jurisdictional litigation involving very complicated questions of conflict of contract laws and applicable consumer protection regimes is not suitable for the relatively small values at stake'. ${ }^{44}$

Kleinsteuber notes that 'laws cannot regulate the Internet in many cases' and 'the Internet as a global medium cannot be caged in by nation-states'. ${ }^{45}$ As such, this author advocates the need for new concepts. In the international arena, the paper 'International Policy on Industry Self-regulation' recognises the importance of self regulation of e-commerce 'as the only useful option because online trades are increasingly crossing jurisdictional boundaries' ${ }^{46}$

However, Gibbons describes the drawbacks of the self-regulatory approach in the following manner:

Alternatively, a laissez-faire market solution focusing solely on consumer action is even less likely to succeed, because the process is not transparent. Consumers do not have the time or the incentive to investigate ODR options until the post-contract dispute arises. ${ }^{47}$

It also seems that affirmative legislations to regulate ODR may not be successful on their own due to the changing nature of the technology and business models. ${ }^{48}$ Therefore, it is evident that some writers favour the hybrid approach as the most suitable approach in this respect and make analyses of regulatory models with their pros and cons. For example, Gibbons seems to advocate a hybrid approach: 'Regulatory models that provide voluntary safe harbour provisions, coupled with explicit incentives to encourage due process and fair play to ameliorate the repeat-player influence, may be the superior

${ }^{43}$ Gralf-Peter Calliess, 'Online Dispute Resolution: Consumer Redress in a Global Market Place' (2006) 7(8) German Law Journal 647, 654.

${ }^{44}$ Ibid 654-5.

45 Hans J Kleinsteuber, 'The Internet between Regulation and Governance' (undated) 72 $<$ http://www.osce.org/fom/13844>.

${ }^{46}$ The Treasury, Taskforce on Industry Self-Regulation, International Policy on Industry SelfRegulation, $<$ http://archive.treasury.gov.au/documents/1123/HTML/docshell.asp?URL=appd.asp>.

${ }^{47}$ Gibbons, above n 35, 6.

${ }^{48}$ Ibid 6. 
regulatory models.' ${ }^{49}$ The author gives two reasons: 'these models are flexible and are more likely to keep pace with the evolution of e-commerce. ${ }^{50}$ In a similar vein, Morek argues in favour of a co-regulatory model which entails 'a combination of both private and national and international mechanisms, working in a coordinated effort to provide the optimal regulatory framework of online dispute resolution' ${ }^{51}$

This brief literature review indicates the still debated nature of the various regulatory approaches to the regulation of ODR. The next question of how effective the OECD Guidelines and the Australian Guidelines are in terms of providing an appropriate regulatory framework for ODR is worth examining in this regard. From the regulatory perspective of ODR (including OCA), it can be argued that these online consumer protection guidelines have several problematic elements, despite their importance as regulatory sources for the protection of online consumers and the provision of appropriate dispute resolution mechanisms. In view of these theoretical underpinnings of the regulatory models applicable to the regulation of ODR, the following sections explore some problematic aspects of the regulatory approaches advocated in both the OECD Guidelines and Australian Guidelines in the context of the resolution of B2C e-commerce disputes.

\section{REgulatory APPROACHES OF THE OECD AND AUSTRALIAN GUIDELINES}

Before moving to discussion of these problematic aspects of the regulatory approach adopted in the guidelines, it is important to identify the regulatory elements embedded in these guidelines. It seems that there are three regulatory approaches within the parameters of these guidelines.

The first includes the promotion of self-regulatory approach. The OECD Guidelines can be considered a source which allows self-regulation as an appropriate regulatory model. Most importantly, the OECD considers selfregulatory policy 'a legitimate alternative to formal regulation ... being embraced by member countries at different rates'. ${ }^{52}$ The OECD Guidelines have clear principles which promote the development of 'fair, effective and transparent self-regulatory and other policies and procedures, including alternative dispute resolution mechanisms, to address consumer complaints'.

\footnotetext{
${ }^{49}$ Ibid.

${ }^{50}$ Ibid.

${ }^{51}$ Morek, above n 3, 76.

${ }^{52}$ Taskforce on Industry Self-Regulation, above n 46.
} 
In contrast, it should also be pointed out that the self-regulatory approach has not been expressly incorporated into any of the Australian Guidelines, including dispute resolution mechanisms. However, it can be argued that Australian Guidelines promote self-regulatory approach. For example, they require business to provide 'accurate and easily accessible information' about 'the relevant codes of practice of any relevant self-regulatory scheme' to consumers. Their set of principles applicable to B2C e-commerce is one development that reflects commitment towards the regulation of online cross-border activities. ${ }^{53}$ Moreover, its formation seems to be influenced by both the OECD Guidelines ${ }^{54}$ and Australia's policy approach to the regulation of e-commerce. ${ }^{55}$

The second regulatory approach deals with applicable laws and jurisdictions, and national consumer protection laws. In order to protect online consumers, these oblige member countries to ensure online consumer protection 'through their judicial, regulatory, and law enforcement authorities co-operate at the international level'. ${ }^{56}$

The third approach seems to be a co-operative regulatory approach. It appears that the promotion of the self-regulatory approach, backed by a supportive legislative framework for the regulation of online consumer activities, including appropriate dispute resolution mechanisms which can be used for the resolution of B2C e-commerce disputes, could be valuable. For example, the OECD Guidelines also advocate the development of co-operative self-regulatory programs:

ii) Businesses and consumer representatives should continue to establish cooperative self-regulatory programs to address consumer complaints and to assist consumers in resolving disputes arising from business-to-consumer electronic commerce. ${ }^{57}$

53 See also Elisabeth Wentworth, 'Online Dispute Resolution: Global Issues and Australian Standards’ (2002) 21(2) The Arbitrator \& Mediator 21.

${ }^{54}$ Consumer and Business Affairs, Victorian Department of Justice, The Best Practice Model Translates the OECD Guidelines for the Australian Context, Web Seals of Approval Discussion Paper (January 2002) <http://www.consumer.vic.gov.au/library/publications/resources-andeducation/research/web-seals-of-approval-2002.pdf>.

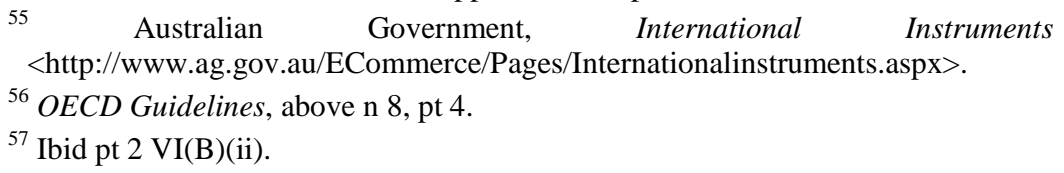

${ }^{56}$ OECD Guidelines, above n 8, pt 4.

${ }^{57}$ Ibid pt 2 VI(B)(ii). 
However, it can be argued that the drawbacks associated with the selfregulatory, statutory approaches and co-operative regulatory approach could undermine the objective of promoting the self-regulatory approach backed by a supportive legislative framework, and so could diminish the viability of guidelines as a source of regulatory models for the regulation of ODR in the broader debate over the appropriate regulatory models for regulation.

\section{A Viability of the Self-Regulatory Approach}

Arguably, the self-regulatory approach embedded in the current online consumer protection guidelines does not provide an appropriate regulatory foundation for the development of ODR. The viability of this approach can be questioned from several perspectives. The first question relates to the lack of definition of self-regulation, ${ }^{58}$ which impedes understanding of the scope of the self-regulatory framework. Neither the OECD Guidelines nor the Australian Guidelines provide a set of specific principles which could be useful when the private sector designs its own self-regulatory mechanisms. At least, drafters of these guidelines could have clarified the consequences of applying selfregulations for the resolution of B2C e-commerce disputes.

The second question is whether either set of guidelines have binding force. Unfortunately, they do not, ${ }^{59}$ which could render their objectives futile. Does this mean that the OECD Guidelines and the Australian Guidelines have no influence over the sectors that come under these instruments? Vilalta's view is that '[ $t$ ]he fact that it is not a binding instrument does not constitute a real obstacle, but a value for the states that are competent in their internal strategies at a domestic level' ${ }^{60}$ This could be because governments are likely to develop appropriate laws in line with these guidelines as 'there is a strong moral obligation for the Member countries to utilise and implement these policy recommendations, which they themselves have jointly drafted'. ${ }^{61}$

\footnotetext{
${ }^{58}$ See Monroe E Price and Stefaan G Verhulst, Self-Regulation and the Internet (Kluwer Law International, 2005) 3 where they indicate that ' $[\mathrm{t}]$ here is no single definition of self-regulation that is entirely satisfactory, and indeed, there should not be'. Furthermore, these two writers note that '[s]elf-regulation ... consists of a series of representations, negotiations, contractual arrangements, and collaborative efforts with government. Self-regulation on the Internet is a subtle and changing combination of all of these activities' and 'self-regulation can be seen as the range of activity by private actors undertaken to prevent more intrusive and more costly action by government itself. In that sense, self-regulation can be explained as a collective economic decision-an intersection of maximization of profit and expressions of public interest': at 5 .

${ }^{59}$ OECD, Guidelines for Consumer Protection in the Context of Electronic Commerce Frequently Asked Questions (FAQ) <http://www.oecd.org/sti/consumerpolicy/2091663.pdf>.

${ }^{60}$ Vilalta, above n 5, 106.

${ }^{61}$ FAQ, above n 59 .
} 
Moreover, private online businesses and consumers could design their dispute resolution mechanisms to reflect these guidelines so that online consumers would then have some form of regulatory backing for their online activities with online businesses. However, according to some scholars, the self-regulatory approach of the guidelines is not effective due to its lack of binding force. ${ }^{62}$

The lack of binding force of these guidelines could lead to compliance problems. NADRAC notes that '[s]ome ADR service providers, whether individuals or organisations, may choose to ignore accepted standards of ADR practice'. ${ }^{63}$ This potential for negative behaviour raises the question as to whether the self-regulatory approach can in fact have a positive influence on the private sector, if it can ignore the standards of ODR.

The other drawback relates to the nature of the compliance mechanisms enshrined in the guidelines ${ }^{64}$ In responding to the issue of non-compliance, Segal indicates that 'it must have effective compliance monitoring and enforcement mechanisms, be underpinned by efficient dispute resolution processes'. ${ }^{65}$ Eijlander confirms this view within his definition of selfregulation, by maintaining that '[s]elf-regulation in its pure form can be defined as regulation by organisations or associations in a field of society; not only do they create the rules, but they also monitor compliance with these rules and enforce them against their own members'. ${ }^{66}$

It seems clear that there are principles in both the OECD Guidelines and the Australian Guidelines that support the development of an institution to monitor compliance with the guidelines as well as self-regulatory measures. The OECD Guidelines encourage member countries 'to review and, if necessary, promote

\footnotetext{
${ }^{62}$ Smith, above n 11, 188; Marita Shelly and Professor Margaret Jackson, 'Doing Business with Consumers Online: Privacy, Security and the Law' (2008) 17(2) International Journal of Law and Information Technology 180, 186.

63 NADRAC, A Framework for ADR Standards - Report to the Commonwealth AttorneyGeneral (2001) $<$ http://www.nadrac.gov.au/publications/PublicationsByDate/Documents/BodyofReport.pdf>.

${ }^{64}$ Morek, above $\mathrm{n}$ 3, 38 notes that 'there would be no enforcing or supervisory body to ensure that an ODR provider really complies with these principles in practice'.

${ }^{65}$ Jillian Segal, Institutional Self-Regulation: What should be the Role of the Regulator? (2001) 7

$<$ http://www.asic.gov.au/asic/pdflib.nsf/LookupByFileName/NIGConf_081101.pdf/\$file/NIGCon f_081101.pdf $>$.

${ }^{66}$ Philip Eijlander, 'Possibilities and Constraints in the Use of Self-Regulation and Co-Regulation in Legislative Policy: Experiences in the Netherlands - Lessons to Be Learned for the EU?' (2005) 9 Electronic Journal of Comparative Law 1, 2 <http://www.ejcl.org/91/issue91.html>.
} 
self-regulatory principles to encourage development of effective self-regulatory mechanisms that contain specific, substantive rules for dispute resolution and compliance mechanisms' ${ }^{67}$ The problem is that there is no formally recognised institution or any formal enforcement mechanism within these guidelines. ${ }^{68}$

This lack of any specific enforcement mechanism raises the question of whether having a central authority that can operate nationally and internationally is important, or whether nationally available government-sponsored consumer protection enforcement mechanisms can be utilised to fill this vacuum. Some developments can be seen within the OECD framework, in national and international contexts, which could be considered promising developments in terms of improving the compliance mechanism for the principles embedded in these guidelines and national consumer protection laws. Three examples can be cited in this regard.

First, it must be noted that there is an existing compliance mechanism in the online consumer protection guidelines. The OECD hopes to achieve compliance through a peer review process. ${ }^{69}$ The OECD notes that '[t]hese "soft" laws are nonetheless effective thanks to the OECD's highly developed process of peer review'. ${ }^{70}$ However, it seems that such a peer review process has not been commenced in the area of ODR for the resolution of B2C e-commerce crossborder disputes.

Secondly, there are some further developments that could be utilised to enhance the compliance with the guidelines in general and self-regulation measures in particular. For example, in the Australian national context, a recent development is the Mediator Standards Board (MSB), which could play a pivotal role in this respect. The MSB (launched in 2010) ${ }^{71}$ as a main body reflects the sectorspecific practical approach to the development of ADR in Australia because it is

${ }^{67}$ Taskforce on Industry Self-Regulation, above n 46; see also OECD Guidelines, above n 8.

${ }^{68}$ See also Smith, above n 11, 168; Shelly and Jackson, above n 62.

69 OECD, Peer Review Process: A Tool for Co-operation and Change <http://www.oecd.org/site/0,3407,en_21571361_37949547_1_1_1_1_1,00.html>.

70

OECD,

Information

Disclosure

<http://www.oecd.org/document/26/0,3746,en_2649_34495_33945946_1_1_1_1,00.html>:

'The OECD, through its committees, facilitates the production of internationally agreed instruments, decisions and recommendations. Decisions and treaties negotiated within the OECD are legally binding whereas recommendations are not legally binding and are considered as "soft" law.'

${ }^{71}$ MSB, About Us, <http://www.msb.org.au/about-us>. 'The launching of the MSB today reflects positively on the willingness of the mediation profession in Australia to achieve self regulation and to collaborate to establish a body of standards, notwithstanding the diversity of the field and its respective differences': Murray Kellam AO, Speech delivered at the 10th National Mediation Conference Adelaide, 7 September 2010, 1. 
responsible for the development of mediator standards and the implementation of the National Mediator Accreditation System (NMAS). ${ }^{72}$ This is a promising development for the evolution of standards applicable to online mediation; however, it is still questionable whether this body has a mandate to cover the other ADR mechanisms, such as online conciliation and online arbitration.

Thirdly, in the international context, there are existing institutional mechanisms which could be used for this purpose. The International Consumer Protection and Enforcement Network (ICPEN) ${ }^{73}$ to which the Australian Competition and Consumer Commission (ACCC) belongs, could be considered promising thanks to its cross-border enforcement element, which suits the B2C e-commerce cross-border environment. This mechanism could be developed to monitor the enforcement of the guidelines, but also as an effective dispute resolution mechanism in the cross-border B2C e-commerce context. It can be further argued that this international initiative, combined with national enforcement bodies, resembles the co-ordinated approach advocated by the OECD Guidelines and the Australian Guidelines and would enable a higher commitment to compliance with self-regulatory measures by ODR service providers.

\section{B Conflict of Law Rules and Consumer Protection Laws}

\section{$1 \quad$ Applicable Law and Jurisdiction under the OECD Guidelines}

Both the OECD and Australian Guidelines contain principles with regards to conflict of law rules. Conflict of law rules, also called 'private international law rules', are utilised to resolve 'conflicts between legal systems'. ${ }^{74}$ This may include one country where different laws are applied in different states, such as in Australia. As Svantesson notes, 'each state makes its own private

\footnotetext{
${ }^{72}$ Ibid: 'The creation of one central entity responsible for mediator standards and accreditation is a landmark development in the history of mediation in Australia.'

73 International Consumer Protection and Enforcement Network, Protecting Consumers Worldwide $<$ https://icpen.org/>.

${ }^{74}$ M Davies, A S Bell and P L G Brereton, Nygh's Conflict of Laws in Australia (LexisNexis, $8^{\text {th }}$ ed, 2010) 7. See Reid Mortensen, Richard Garnett and Mary Keyes, Private International Law in Australia (LexisNexis, $2^{\text {nd }}$ ed, 2011) 4: 'In Australia, other common law countries and civil law countries, private international law is concerned with these three issues: jurisdiction, the recognition and enforcement of foreign judgments, and choice of law.'
} 
international law rules (ie the private international law rules are part of the domestic law of each state), ${ }^{75}$

Some of the OECD Guidelines allow conflict of law rules which are nationally and internationally applicable to be applied to B2C cross-border e-commerce transactions, eg:

Business-to-consumer cross-border transactions, whether carried out electronically or otherwise, are subject to the existing framework on applicable law and jurisdiction. ${ }^{76}$

There are, however, several drawbacks embedded in the Guidelines. For example, the phrase 'the existing framework on applicable law and jurisdiction' refers to the established conflict of law rules which exist nationally and internationally. This guideline is broadly designed to apply the existing applicable law and jurisdiction-related legal framework to B2C cross-border transactions which take place either electronically or otherwise. This approach seems to be fruitless and shows no sign of making any initial attempt to demarcate basic principles in relation to applicable law and jurisdiction with a focus on the B2C cross-border e-commerce disputes and ODR mechanisms.

Instead of adopting such a targeted approach, the OECD encourages 'governments, businesses, consumers and their representatives to participate in and consider the recommendations of ongoing examinations of rules regarding applicable law and jurisdiction'. OECD Guideline VI(A) notes that consideration must be given to modifying the existing legal framework in regards to applicable law and jurisdiction in order 'to ensure effective and transparent consumer protection in the context of the continued growth of electronic commerce'. Referring to modification of the existing legal framework relevant to applicable law and jurisdiction, VI(A) stipulates that 'governments should seek to ensure that the framework provides fairness to consumers and businesses [and] facilitates electronic commerce'.

The next question is whether the OECD and its member countries have taken effective measures to overcome issues associated with conflict of law rules applicable to the B2C cross-border setting. In other words, can these obligations be fulfilled by OECD member governments in the situation of cross-border B2C e-commerce at present? The answer seems to be no.

\footnotetext{
${ }^{75}$ Dan Svantesson, 'An Introduction to Jurisdictional Issues in Cyberspace’ (2004) 15 Journal of Law, Information and Science $<$ http://www.austlii.edu.au/au/journals/JlLawInfoSci/2004/3.html>.

${ }^{76}$ OECD Guidelines, above n 8, Guideline VI(A).
} 
As far as the OECD is concerned, the OECD itself acknowledges that 'rules regarding applicable law and jurisdiction in the consumer context could have implications for a broad range of issues in electronic commerce, just as rules regarding applicable law and jurisdiction in other contexts could have implications for consumer protection' ${ }^{77}$ Moreover, it is mentioned in the OECD Guidelines' Frequently Asked Questions (FAQ) that '[t]he language on jurisdiction and applicable law within the Guidelines reflects the complexity and the current lack of international consensus on these issues' ${ }^{78}$ It has been stated in the OECD Conference on Empowering E-consumers Strengthening Consumer Protection in the Internet Economy Background Report that '[o]ver the past decade, the 1999 Guidelines have been widely promoted and adopted by stakeholders through (i) new or adapted regulatory frameworks, (ii) private sector initiatives, and (iii) consumer education initiatives'. ${ }^{79}$ Even though these developments have some merit in relation to online consumer protection, there is no committed approach to at least put forward a basic set of principles in relation to conflict of law rules on the resolution B2C electronic commerce disputes.

The lack of a harmonised approach to jurisdiction and applicable law is also reflected in the responses given to the survey conducted by the OECD. ${ }^{80}$ Unfortunately, the situation seems to exist without necessary changes being brought by the OECD, as indicated in the statement made during the OECD conference in 2010 that 'the various approaches to choice of law and rules on jurisdiction complicate the matter. Consumer rights and obligations may vary considerably from one jurisdiction to another ${ }^{31}$ As such, it can be argued that the OECD has not produced an internationally developed, harmonised legal

\footnotetext{
${ }^{77}$ Ibid.

${ }^{78} \mathrm{FAQ}$, above n 59.

${ }^{79}$ OECD, Conference on Empowering E-consumers: Strengthening Consumer Protection in the Internet Economy, Background Report (December 2009) 14 $<$ http://www.oecd.org/document/50/0,3746,en_21571361_43348316_43385778_1_1_1_1,00.ht $\mathrm{ml}>$ : 'In most OECD countries, regulations on information disclosure requirements for business pre-date the 1999 Guidelines. To adapt these rules to the online environment, further ecommerce specific instruments including laws, regulations, and guidance, have been adopted over the years, or are being developed by countries. These instruments address a range of related issues including fraud, spam, privacy, security, enforcement, and dispute resolution and redress.'

${ }^{80}$ Ibid 17.

${ }^{81}$ OECD, Conference on Empowering E-Consumers: Strengthening Consumer Protection In The Internet Economy, Summary of Key Points and Conclusions, Directorate for Science, Technology and Industry Committee on Consumer Policy (2010) $<$ http://www.oecd.org/dataoecd/32/10/45061590.pdf>.
} 
framework in terms of jurisdiction and applicable law relating to B2C crossborder e-commerce transactions.

A similar situation is reflected in the enforcement of foreign judgments that can be delivered in B2C e-commerce disputes. In relation to the enforcement of judgments delivered by government-sponsored courts, the OECD Guidelines states that countries should 'co-operate and work toward developing agreements or other arrangements for the mutual recognition and enforcement of judgments resulting from disputes between consumers and businesses' ${ }^{82}$ On the face of this, it seems that this guideline recognises the need for appropriate arrangements for the mutual recognition and enforcement of judgments resulting from B2C disputes. From the government perspectives, the failure of current attempts by governments to revise or make a set of internationally applicable modern conflict of law rules, even in the offline context, indicates the difficulty of bringing modifications to the existing legal framework. ${ }^{83}$

International efforts are also failing to address the conflict of law rules applicable to consumer contractual settings. For example, the Hague Convention on Choice of Court Agreements 2005 has excluded consumer disputes ${ }^{84}$ even though it is the counterpart for litigation of the New York Convention on the Recognition and Enforcement of Foreign Arbitral Awards. ${ }^{85}$ The reasons for the exclusion of consumers are related to 'the existence of more specific international instruments, and national, regional or international rules that claim exclusive jurisdiction for some of these matters' ${ }^{86}$ As such, a harmonised approach is advocated to overcome these conflicting and country- or regionspecific regulatory measures taken by governments. ${ }^{87}$ The Australian perspective is noted by Garnett in the following terms:

${ }^{82}$ OECD Guidelines, above n 8, pt 4.

${ }^{83}$ See also Megan Richardson and Richard Garnett, 'Towards and beyond an Australian Private International Law of Cross-Border Communications Disputes' (2006) 11(4) Media and Arts Law Review 331.

${ }^{84}$ Marta Pertegás, 'The Brussels I Regulation and the Hague Convention on Choice of Court Agreements' (2010) 11(1) ERA-Forum 19, 20.

85 J J Spigelman AC, 'The Hague Choice of Court Convention and International Commercial Litigation' (Paper presented at the conference on Commonwealth Law Conference, Hong Kong, 7

April 2009)

<http://www.lawlink.nsw.gov.au/lawlink/Supreme_Court/ll_sc.nsf/vwFiles/spigelman070409.pd f/\$file/spigelman070409.pdf $>$.

${ }^{86}$ The Hague Convention of 30 June 2005 on Choice of Court Agreements, Outline of the Convention (February 2012) 2 <http://www.hcch.net/upload/outline37e.pdf>.

87 See, eg, Moira Patterson, E-commerce Law (2001) $<$ http://www.apec.org.au/docs/paterson.pdf>: 'In an Internet environment, this means that any rights or penalties must be enforceable on a global basis. This in turn requires harmonisation of 
What is required to achieve this outcome is that governments and courts of nation states put aside their parochial, domestic interests in favour of the goal of multilateral harmonisation. It will be only then that the Convention may truly come to be seen as the counterpart to the New York Convention on arbitral agreements and awards. ${ }^{88}$

When it comes to electronic commerce, it is natural that further complexities and challenges will emerge in the modification of existing rules of applicable law and jurisdiction.

The current enforcement of foreign judgments is based on the laws individually developed or on regionally developed mechanisms; for example, the Foreign Judgments Act 1991 (Cth) can be cited for the first and the European Council Regulation on Jurisdiction and the Recognition and the Recognition and Enforcement of Judgments in Civil and Commercial Matters 2000 for the second. ${ }^{89}$ This regulation has also excluded its application to 'arbitration' ${ }^{90}$ In fact, it must be noted that some measures are being discussed towards developing harmonised legal approaches in the form of Model Laws for jurisdiction and applicable law for consumer contracts from regional perspectives. $^{91}$

legal frameworks to better enable dispute resolution and redress in respect of breaches of the rights of intellectual property owners, consumers and other e-commerce participants.'

${ }^{88}$ Richard Garnett, 'The Hague Choice of Court Convention: Magnum Opus or Much Ado about Nothing?' (2009) 5 Journal of Private International Law 161, 180.

${ }^{89}$ Regulation (EC) No 44/2001 of the European Council of 22 December 2000 on Jurisdiction and the Recognition and Enforcement of Judgments in Civil and Commercial Matters [2000] OJ L 12/1, European Judicial Network, in civil and commercial matters, Enforcement of Judgments - Community Law (November 2009) ('Regulation (EC) No 44/2001') $<$ http://ec.europa.eu/civiljustice/enforce_judgement/enforce_judgement_ec_en.htm>; Henrik Ringbom, 'EU Regulation 44/2001 and its Implications for the International Maritime Liability Convention' (2004) 35 Journal of Maritime Law \& Commerce 1, 3.

${ }^{90}$ Regulation (EC) No 44/2001, above n 89, art 1(2)(d).

${ }^{91}$ Diego Fernandez Arroyo, 'Current Approaches towards Harmonization of Consumer Private International Law' (April 2009) 58(2) International and Comparative Law Quarterly 411, 411, $417<$ http://journals.cambridge.org/action/displayIssue?iid=5469284>. The proposals made by the governments such as Brazil, Canada and the United States are listed respectively: 'Buenos Aires Proposal', 'the Draft Model Law on Jurisdiction and Applicable Law on Consumer Contracts' and 'the US government presented a revised version of its proposal, which consists in Legislative Guidelines for an Inter-American Law on the Availability of Mechanisms for Consumer Dispute Resolution and Redress for Consumers, along with four model laws.' Permanent Council of the Organization of American States Committee on Juridical and Political 
Thus it is evident that the drafters of the OECD Guidelines have paid insufficient attention to producing a specific set of principles relevant to applicable law and jurisdiction which can be applied to B2C cross-border e-commerce disputes. Unfortunately, the drafters have left problems associated with applicable law and jurisdiction to be determined by traditional legal principles, which are largely irrelevant to B2C e-commerce disputes.

\section{$2 \quad$ Applicable Law and Jurisdiction under the Australian Guidelines}

As far as Australian conflict of law rules applicable to cross-border e-commerce are concerned, the most salient observation is that there is no specific legal framework in relation to the jurisdiction of internet disputes, as Garnett makes clear that ' $[\mathrm{t}]$ here are currently no specific provisions on jurisdiction and applicable law in relation to electronic commerce disputes under Australian law, ${ }^{92}$

Unfortunately, it can be argued that the Australian guidelines do not provide specific guidance in terms of jurisdiction and applicable law tailored to B2C e-commerce disputes. This argument can be supported by examining two important guidelines referring to applicable law and jurisdiction. It appears that Guideline 48 deals with applicable law and jurisdiction to the B2C cross-border e-commerce disputes, and Guideline 49 governs applicable law and jurisdiction within Australia. Both of these principles need to be discussed. For clarity, each warrants a separate focus, as 48 applies to the international context and 49 applies only to the Australian national context. Guideline 48 stipulates:

48. Where a business specifies an applicable law or jurisdiction to govern any contractual disputes or a jurisdiction or forum where disputes must be determined, it should clearly and conspicuously state that information at the earliest possible stage of the consumer's interaction with the business.

As far as the scope of Guideline 48 is concerned, businesses should specify information clearly and conspicuously in regards to the 'applicable law or jurisdiction' and dispute resolution mechanism at the earliest stage of interaction with the consumer. Under this principle, a business can choose the applicable law and specify which forum has the jurisdiction to determine disputes in case of a dispute which may emerge out of a B2C e-commerce contract.

Affairs, Report of the Coordinator of the Informal Working Group (May 2010) $<$ http://www.oas.org/dil/CP-CAJP_2874-10_eng.pdf >

${ }^{92}$ Richard Garnett, Report to the European Commission: 'Section 1: The Applicability of Private International Law to Online Transactions' 2: 'It is therefore necessary to examine the general law principles of jurisdiction based on both "common law” and statutory principles.' 
It can be argued that this Guideline does not provide specific and clear information about the obligation of businesspeople to specify 'an applicable law or jurisdiction'. The wording appears to be unclear, reflected by the wording, 'information at the earliest possible stage of the consumer's interaction with the business'. The concern is that it is left open at what stage of the interaction between businesses and consumers businesses should specify 'an applicable law or jurisdiction'. Is it sufficient to state such information on the website with which the consumer interacts, or before the formation of contractual obligations, or at the point where the business enters into an agreement with the consumer?

It can also be argued that this principle enables businesspeople to determine both applicable law and forum for the resolution of disputes which may arise out of contractual arrangements between online businesspeople and online consumers. Online businesspeople thus have two options: the first is to apply self-regulatory rules as applicable laws to such disputes and ODR mechanisms as appropriate forums, both of which are designed by online businesspeople. The second option is the selection of the national court of a particular country as the forum and the laws of the same forum country or another country as applicable laws.

As far as the first option is concerned, this principle adopts a flexible approach to the issue of the choice of applicable law and jurisdiction in the resolution of contractual disputes, given the cross-border dimension of B2C e-commerce disputes. Accordingly, it can be argued that such an approach is in compliance with the rationale behind the emergence of ODR. In this it is recognised that ODR mechanisms emerged as an appropriate solution to overcome the drawbacks associated with legal frameworks and with these traditional dispute resolution mechanisms. For example, Muñoz-López notes one important aspect of the rationale behind the development of ADR and ODR in the following terms: 'ADR offline can be successfully used to evade the conflict of laws complicated process. The jurisdiction problem is immediately solved. ${ }^{93}$ This scholar further notes that 'ODR goes beyond as it not only solve the problem of

93 José Edgardo Muñoz-López, 'Internet Conflict of Laws: A Space of Opportunities for ODR' (2009) 14 International Law, Revista Colombiana de Derecho Internacional 163, 182. $<$ http://scholar.google.com/scholar?q=+Internet+Conflict+of+Laws\%3A+A+Space+of+Opportu nities+for+ODR\%2C+\&hl=en\&as_sdt=0\%2C5> . 
the conflict of laws process but also is successful in reducing legal costs and time consumption for business disputants'. ${ }^{94}$

Importantly, in the context of cross border B2C e-commerce disputes, the selected applicable law and forum will not provide a positive solution because of the problematic nature of the variation in national laws and courts in any particular country. Any applicable law or jurisdiction clauses which include those of another country could be problematic unless they comply with the Australian CCA. ${ }^{95}$ For example, if these clauses are embedded in standard form contracts between online businesspeople and Australian online consumers, which are known as 'take it or leave it' contracts, such clauses may be unfair and as a result they may become void if they do not comply with the fairness test of the CCA.

In cases where such clauses are designed unilaterally by businesspeople, leaving no opportunity for consumers to be involved in the formation of such contracts, ${ }^{96}$ they could be declared void by the Australian judiciary. ${ }^{97}$ A similar result could be produced in a case where a mandatory OCA clause is incorporated in a B2C cross-border e-commerce standard form contract because such a clause would deny the consumer access to a government-sponsored court. ${ }^{98}$ As a result, it can be argued that the intended purpose of this guideline can be diminished.

At the same time, given the absence of court decisions that deal with ODR and access to courts, some insights into the problem can be drawn from the decisions delivered by the Australian courts in internet disputes: '[S]pecial features of the Internet present peculiar difficulties for the legal regulation of its content and, specifically, for the exclusion of access in defined jurisdictions. ${ }^{99}$

In the absence of a clear legal approach to dealing with how to establish jurisdiction and applicable law in the case of B2C cross-border e-commerce disputes, Australia faces the challenge of either updating existing laws or introducing a new set of laws which address the issues associated with applicable law and jurisdiction over internet disputes. Such progressive moves

\footnotetext{
${ }^{94}$ Ibid; see also Henry H Perritt Jr, 'Dispute Resolution in Cyberspace: Demand for New Forms of ADR' (2000) 15 Ohio State Journal on Dispute Resolution Journal 675.

${ }^{95}$ CCA, vol 3, sch 2, pt 2-3.

${ }^{96}$ Ibid.

97 Australian Consumer Law, A Guide to the Unfair Contract Terms Law (2010) 7 $<$ http://www.consumerlaw.gov.au/content/Content.aspx?doc=the_acl/guidance.htm>.

${ }^{98}$ CCA, s 25(k): 'a term that limits, or has the effect of limiting, one party's right to sue another party.'

${ }^{99}$ Dow Jones and Company Inc v Gutnick [2002] HCA 56 [87].
} 
need to be in line with developments taking place in other countries and to have some flexibility in their structure in order to adjust with evolving technology. ${ }^{100}$ Such an online jurisdiction-specific legal approach would enable the national courts to become an appropriate final redress mechanism for the online consumer. Importantly, Australia could develop specific model laws addressing issues associated with jurisdiction, applicable law and the enforcement of foreign judgments tailored to the B2C e-commerce setting in line with the developments taking place in the EU, the United States, Canada and Brazil.

Guideline 49 stipulates:

49. A business located in Australia that enters into a contract with a consumer whom the business believes is resident in Australia — for instance, because of the consumer's address — should spell out which Australian jurisdiction's law is the governing law of that contract. It should also make clear that any contractual disputes will be heard by Australian courts and tribunals.

This Guideline is designed to address both the governing laws of B2C ecommerce contracts and jurisdiction within Australia. Three features can be identified: (1) the governing law of the contract must be an Australian jurisdiction's law, which avoids the use of foreign law as the governing law of such contracts; (2) the appropriate forum for the resolution of any dispute arising out of such a contract is Australian courts and tribunals; and (3) this is an attempt to reduce the use of conflict of law rules. These elements can be considered positive developments from the online consumer protection perspective.

However, there are some drawbacks in regards to the Guideline, which states that 'it should also make clear that any contractual disputes will be heard by Australian courts and tribunals'. Does this mean that the Australian Guidelines recognise both adjudicatory (binding arbitration) and non-adjudicatory ADR mechanisms (facilitative ADR mechanisms) or none of these mechanisms? The answer favours the latter. All B2C online disputes which emerge between online businesses located in Australia and online consumers who are residents of Australia have to go to a national court for redress. This principle is arguably a rejection of mandatory online consumer arbitration, whether pre- or post-

\footnotetext{
${ }^{100}$ See also Patterson, above n 87: 'Law by its nature tends to evolve slowly but the exponential growth in the use of Internet requires rapid and well coordinated responses. This difficulty is magnified by uncertainty concerning the nature and implications of future technological developments'.
} 
mandatory arbitration mechanisms. The other question is: can a consumer who has a small-dollar dispute seek remedy through a national court or undefined tribunal in Australia, where the cost of receiving redress can be higher than the actual cost suffered by the consumer?

Moreover, does this mean that a business located in Australia can go to a national court, public tribunal or private tribunal in case of a contractual dispute? What does 'tribunals' mean? This word is not defined in the definition section of the guidelines. This lack of definition in regards to 'tribunals' makes the application of this guideline unclear and so basically worthless from the perspective of online consumer protection.

Ghoshray notes that 'in practice, parties are not bound to submit to a particular jurisdiction and choice of law. They are free to choose their own jurisdictions and laws' ${ }^{101}$ However, it is evident that this freedom is restricted due to the compelling element of the choice of applicable law and jurisdiction in the Australian Guidelines.

The other question relates to whether consumers can oppose such a unilateral arrangement in cases where a business unilaterally determines an applicable law and a forum for the resolution of B2C e-commerce disputes. The Guideline's approach seems to neglect the consumer's right to refuse any arrangement of governing laws of contracts and forums for the resolution of any disputes arising out of their contract.

Another problematic aspect is that neither the OECD Guidelines nor the Australian Guidelines address the situation where a business omits the specification of an applicable law or a forum in which to determine any dispute which arises from a B2C contract - in other words, whether conflict of law rules can be applied or not.

\section{Consumer Protection Law}

It can also be argued that the OECD has not gone beyond national consumer protection laws. The OECD Guidelines make specific reference to the need to give priority to national consumer protection. Thus the OECD Guidelines drafters note that 'nothing contained herein should restrict any party from exceeding these guidelines nor preclude Member countries from retaining or adopting more stringent provisions to protect consumers online'.

101 Saby Ghoshray, 'Charting the Future of Online Dispute Resolution: An Analysis of the Constitutional and Jurisdictional Quandary’ (2006) 38 University of Toledo Law Review 317, 329. 
In contrast, the Australian Guidelines highlight the reliance of online consumer protection on existing national consumer protection laws. This approach can be justified from the consumer protection perspective, but when this is considered from both consumer protection and online business perspectives in combination, there are some drawbacks which can undermine the strength of these guidelines.

One such area is the current approach of the guidelines, which apply whatever position is taken by national consumer protection laws in regards to applicable law, jurisdiction and different types of online consumer arbitration scenarios. For example, it is evident that there is a lack of express provisions in both Australian national consumer protection laws and online consumer protection guidelines as to the validity of pre-dispute and post-dispute OCA clauses. ${ }^{102}$

The other problematic aspect of these guidelines is the recognition of access to the courts, which can become a complex and inappropriate option for the B2C e-commerce scenario. The Australian Guidelines advocate access to the courts, with sections specifically ensuring compliance with access to the courts. For example, each of the internal and external dispute resolution mechanisms of the Australian Guidelines entails provisions such as:

43. Businesses should set up internal procedures to handle consumer complaints:

43.4 without prejudicing the rights of the consumer to seek legal redress.

47. This independent method of dispute resolution should be:

47.7 without prejudice to judicial redress. ${ }^{103}$

The appropriateness of national courts as a viable forum is questionable, due to their complex and time-consuming nature. Many writers have highlighted that national courts are not well equipped to resolve small-claims disputes and technology-related disputes. National courts are considered inappropriate for several reasons, with Schultz noting that:

Courts are not likely to be the primary resolvers of most small- and mediumsized disputes occurring in cyberspace - which are the majority of

\footnotetext{
${ }^{102}$ Instead, such clauses are addressed through a contractual legal approach, subjecting their validity to being tested against the test of fairness incorporated in the CCA.

${ }^{103}$ Australian Guidelines, above n 9. Reference No 5 appeared at the end of 43.4 - 'Australian Standard AS4269-1995 provides a guide to good practice in complaint-handling’ was omitted.
} 
e-commerce disputes involving ODR providers - because courts are too slow and expensive. This is a general problem caused by the ubiquity of cyberspace, which clashes with the territoriality of jurisdiction and judicial authorities. $^{104}$

Moreover, Cortes notes that ' $[t]$ here is a clear consensus that our courts cannot provide a system that will effectively meet the needs of consumers in the new global marketplace, and that a global ODR network is the best solution to deal with consumer disputes'. ${ }^{105}$ In the recent OECD conference, it was also indicated that 'in those cases where e-commerce transactions involve small amounts of money, consumers tend not to go to court when things go wrong'. ${ }^{106}$ As a solution, it is further recognised that 'effective, low-cost and adaptive online dispute resolution and redress mechanisms might help to address this' ${ }^{107}$

As such, it is questionable as to how far objectives of the guidelines such as 'are designed to help ensure that consumers are no less protected when shopping online than they are when they buy from their local store or order from a catalogue ${ }^{108}$ have been achieved nationally and internationally when it comes to conflict of law rules and the development of national consumer protection laws.

\section{Attention to Developing a Co-operative Regulatory Approach}

Instead of creating specific benchmarks to address issues associated with ODR in general and OCA in particular, these guidelines promote a co-operative approach to be followed for dealing with $\mathrm{B} 2 \mathrm{C}$ cross-border e-commerce-related issues. The Australian Guidelines are not based on co-operative principles like the OECD Guidelines of $1999,{ }^{109}$ despite the fact that both instruments have

\footnotetext{
${ }^{104}$ Schultz, above n 24, 84.

105 Cortes, above 24. See also Lilian Edwards and Caroline Wilson, 'Redress and Alternative Dispute Resolution in EU Cross-Border E-Commerce Transactions' (2007) 21 International Review of Law, Computers \& Technology 315, 320: 'Why do e-commerce customers not turn to the courts? Clearly, even conventional "high street" consumer disputes are rarely if ever litigated, due to (i) consumer ignorance and apathy as to legal remedies, (ii) the typically low cost of the items in dispute relative to (iii) the high cost of access to legal advice and judicial resolution.'

${ }^{106}$ OECD Technology and Industry Committee on Consumer Policy, above n 81, 8. ${ }^{107}$ Ibid.

108 OECD, Better Policies for Better Lives $<$ http://www.oecd.org/internet/consumerpolicy/oecdguidelinesforconsumerprotectionintheconte xtofelectroniccommerce1999.htm>.

${ }^{109}$ Even though the Australian Guidelines are based on the OECD 1999 Guidelines, they are limited in scope compared to the scope of the OECD Guidelines.
} 
been designed for the B2C cross-border e-commerce setting. As such, the following section explores whether the OECD Guidelines promote a cooperative approach that can be applied to strengthening the enforcement of OCA. It is argued that this instrument does not advocate a specific model for such a purpose and as a result the effectiveness of the guidelines is in doubt. The following guidelines are highlighted in this regard.

In relation to the co-operative aspect of the dispute resolution guidelines, OECD Guideline VI(B) recognises the obligation of business, consumer representatives and government:

VI(B) Businesses, consumer representatives and governments should work together to continue to use and develop fair, effective and transparent selfregulatory and other policies and procedures, including alternative dispute resolution mechanisms, to address consumer complaints and to resolve consumer disputes arising from business-to-consumer electronic commerce, with special attention to cross-border transactions.

Accordingly, Guideline VIB(ii) addresses the co-operative approach between business and consumer representatives in terms of establishing 'self-regulatory programs to address consumer complaints'. VIB(iii) entails the obligation of business, consumer representatives and government to provide effective ADR mechanisms for the resolution of business to consumer e-commerce disputes.

In addition, both the OECD Guidelines and the Australian Guidelines promote fair, timely and cost-effective ADR mechanisms. For example, OECD Guideline VIB(i) requires both business and consumer representatives to establish ADR mechanisms which they should operate in compliance with the principles of fairness, timeliness, avoidance of undue cost and undue burden.

Moreover, the OECD Guidelines provide that it is an obligation of the government to provide a 'meaningful access to fair and timely alternative dispute resolution and redress without undue cost or burden'. The three groups of government, the business sector and consumer representatives are required to develop and use a fair, effective and transparent set of: (1) self-regulatory policies and procedures; and (2) ADR mechanisms to resolve B2C e-commerce disputes.

Additionally, Guideline VIB states that 'further study is required to meet the objectives of Section VI at an international level' and VIB(iv) is also important in this regard as it refers to the innovative use of technology: 
In implementing the above, businesses, consumer representatives and governments should employ information technologies innovatively and use them to enhance consumer awareness and freedom of choice.

As far as the co-operation principle is concerned in general, pt 4 of the OECD Guidelines obliges members to facilitate co-operation and 'where appropriate the development and enforcement of joint initiatives at the international level' among three major groups: businesses, consumer representatives and governments. Part 2 of the OECD Guidelines provides that '[g]overnments, businesses, consumers, and their representatives should work together to achieve such protection and determine what changes may be necessary to address the special circumstances of electronic commerce'. This includes the necessity of finding solutions to e-commerce issues through co-operation among these three stakeholders. If this guideline is interpreted broadly, resolution of edisputes should be conducted with the support of each of these stake holders.

Indeed, it must therefore be noted that consumer protection is recognised through national as well as international co-operation, especially in the OECD Guidelines. For example, pt 4 describes the need for 'building consensus, both at the national and international levels, on core consumer protections to further the goals of enhancing consumer confidence, ensuring predictability for businesses, and protecting consumers'. In addition, interestingly, such consensus needs to be based 'on core consumer protections'. What does this mean? Given the absence of clarification of the scope of core consumer protection, it can be inferred that these can include basic consumer protection principles including effective redress mechanisms which are identified in the consumer protection literature. Hence, these guidelines require consumer rights to be protected at both national and international level.

The OECD Guidelines do not provide a clear definition of the scope of the cooperative principle. This has led to two questions. First, what is meant by cooperation? And, secondly, what are the co-operative measures that can be adopted in order to protect consumer rights? In regard to the first question, at the outset it is already noted that both instruments encourage co-operative approach to achieve consumer protection. In a broader context, two inferences can be made. First, the drafters have intentionally left it to the government and the private sector to develop appropriate measures to protect online consumers without imposing any particular strategies that can undermine the growing online markets. Secondly, the purpose of the guidelines is merely to set a framework for the protection of consumers, which does not necessitate definitional provisions.

From a theoretical perspective, accordingly, the government's co-operation has become imperative because there is a need for leadership and decision-making 
in response to problems such as: the inappropriateness of the application of offline legal frameworks; the lack of international consensus on producing international treaties; and the changing and complex nature of the technology involved in e-commerce activities. Most importantly, if the power imbalance is not adequately addressed and appropriate measures put in place, the progress of the online e-commerce market will be negatively affected and the rights of online consumers will continue to be adversely affected. As such, it should be noted that the government is obliged to develop appropriate methods to regulate the e-commerce environment in a committed and co-operative fashion.

It is also important to note that the underlying rationale behind the principle of co-operation enshrined in the OECD Guidelines seems to be based on several factors: the complex nature of technology; private sector involvement; the transnational dimension of B2C e-commerce disputes; and conflicting national consumer protection laws among countries. ${ }^{110}$ It is also evident that these guidelines do not explicitly provide a legal basis for the development of a cooperative mechanism such as enforcement of OCA awards through e-courts, except for the general intention to guide government, the private sector and consumer groups to take appropriate measures for the protection of consumers through co-operation.

\section{CONCLUding Remarks}

The literature indicates the lack of any specific regulatory model. The more that ODR is used and exposed to technological advances, it is reasonable to predict that there will be more opinions about the appropriate models for its regulation. Of course, conflicting legal approaches and the complex and changing nature of technology will not make it easy for law-makers to produce a stable regulatory framework for ODR. Most importantly, Morek rightly observes that 'it is still difficult to predict which trend in ODR regulation will prevail'. ${ }^{111}$

It must be mentioned that the new wave of ODR-related regulatory approaches in the form of online consumer protection guidelines is a promising development for establishing a secure ODR landscape in its own right within the complex e-commerce market. However, the current regulatory approach advocated by the OECD Guidelines and the Australian Guidelines is arguably vague and full of uncertainties, mainly driven by the problematic aspects

\footnotetext{
${ }^{110}$ See also Patrikios, above n 40.

${ }^{111}$ Morek, above n 3, 70.
} 
associated with the self-regulatory and statutory approaches and the recognition of access to national courts.

These problematic aspects embedded in these instruments could undermine their objectives and also undermine online disputants' confidence, as an ordinary consumer expects an existing regulatory approach to comply with principles such as consistency and predictability, and to possess an adequate regulatory approach for online consumer protection. Unfortunately, these guidelines still apply to the B2C e-commerce platform and they provide an insufficient benchmark for the development of a B2C e-commerce friendly and focused regulatory approach to the regulation of ODR, both internationally and nationally.

It is also timely to revise these online consumer protection guidelines, rather than remaining confined to making recommendations and mere encouragement for those such as 'consumer representatives,' 'governments' and 'businesses and consumers' to adopt co-operative measures for the protection of online consumers in the complex B2C e-commerce market. As such, it can be argued that the existing self-regulatory approach advocated in the OECD Guidelines and the Australian Guidelines needs to be amended by paying specific attention to ODR in general and OCA in particular. 